\section{Birlesik Dünya Arastırma Cypriot Journal of Educational BD-CENTER \\ Sciences}

Innovasyon ve Yayıneılık Merkezi
Volume 15, Issue 5, (2020) 909 - 922

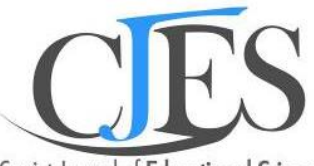

Cypriot Joumal of Educational Sciences

www.cjes.eu

\title{
The mediating role of spiritual orientation and subjective vitality in university students
}

\author{
Neslihan Arici Ozcan ${ }^{1 a}$ : Department of Social Work, Istanbul Medeniyet University, Istanbul, Turkey \\ https://orcid.org/0000-0002-6169-1445 \\ Neslihan Yaman ${ }^{\text {b: }}$ Department of Educational Sciences, Marmara University, Istanbul, Turkey \\ https://orcid.org/0000-0003-0324-2390
}

\section{Suggested Citation:}

Ozcan, N. A., \& Yaman N., (2020). The mediating role of spiritual orientation and subjective vitality in university students. Cypriot Journal of Educational Science. 15(5), 909 - 922. https://doi.org/10.18844/cjes.v15i5.5121

Received 19 May 2020; revised 14 July 2020; accepted from; September 11, 2020. (C)2020 Birlesik Dunya Yenilik Arastirma ve Yayincilik Merkezi. All rights reserved

\begin{abstract}
This study aims to examine the mediating role of spiritual orientation and subjective vitality in the relationship between thriving and life satisfaction among university students. Data were sourced from a total of 527 participants: 428 females (81.2\%) and 99 males (18.8\%), from Istanbul Medeniyet University. The mean age of the participants was 20 (SD = 2.35). The Thriving Scale, Satisfaction with Life Scale, Spiritual Orientation Scale and Subjective Vitality Scale were utilized. Analyses were performed with the Structural Equation Model and The Pearson Product Moment Correlation, Path Analysis and Bootstrapping Test were used. According the road analysis result, the direct effect of spiritual orientation and subjective vitality in life satisfaction proved to be significantly high. The fit values of the model are within acceptable limits $\left(\chi^{2} / \mathrm{SD}=0.00 ; \mathrm{p}<0.01 ; \mathrm{GFI}=0.99 ; \mathrm{CFI}=0.1 ; \mathrm{NFI}=0.99\right.$; RMSEA $=0.00$ ). In the established model, $22 \%$ of the total variance of the life satisfaction variable is explained. The results of the bootstrapping process in the model prove to be significant (bootstrap coefficient model $=0.054,95 \%$ G.A. $=0.022,0.118$ ). The findings were discussed in line with relevant literature and recommendations on their possible application have been given.
\end{abstract}

Keywords: Life satisfaction, mediation, spiritual orientation, subjective vitality, thriving

\footnotetext{
${ }^{1}$ ADDRESS FOR CORRESPONDENCE: Neslihan Arici Ozcan: Istanbul Medeniyet University, Department of Social Work, Istanbul, Turkey

E-mail Address: neslihan.ozcan@medeniyet.edu.tr
} 
Ozcan, N. A., \& Yaman N., (2020). The mediating role of spiritual orientation and subjective vitality in university students. Cypriot Journal of Educational Science. 15(5), 909 - 922. https://doi.org/10.18844/cjes.v15i5.5121

\section{Introduction}

Research on adolescence is largely focused on the mitigation of the risks and challenges faced by young people or preventing these risky behaviors (Benson, Scales, Hamilton \& Sesma, 2007; Bundick, Yeager, King \& Damon, 2010). However, development should be figured out not only from a problem-oriented perspective but also from a strengthened perspective (Bundick et al., 2010; Lerner, Lerner, Bowers \& Geldhof, 2015). Scales, Benson, Leffert \& Blyth (2000) found that developmental strengths provide a decrease in problematic behaviors such as anxiety, outrage, and addiction in adolescents. Positive Youth Development (PYD) emphasizes on the internal and external factors that have a function in the selfdevelopment of young people and their degree of life satisfaction (Lerner, Von Eye, Lerner, Lewin-Bizan \& Bowers, 2010; Pavot \& Diener, 2008; Shek \& Leung, 2013; Sun \& Shrek, 2013). PYD programs also empower especially university students for real-world settings (Kurtines, Ferrer-Wreder, Cass Lorente, Silverman \& Montgomery, 2008). This is because university students should deal with relational, financial, academic, social issues (Hamdan-Mansour, Halabi \& Dawani, 2008; Howard, Schiraldi, Pineda \& Campanella, 2006). In this regard, "thriving" is a much more relevant concept in positive development.

Since the beginning of the 21st century, thriving has emerged in fields of psychology and economics as a psychological state that an individual can experience both learning and vitality, simultaneously (Walumbwa, Muchiri, Misati, Wu \& Meiliani, 2018). 'Vitality' means that an individual has the power to perform a particular behavior (Kleine, Rudolph \& Zacher, 2019). 'Learning' means getting the information and ability to do something in a certain way (Spreitzer, Sutcliffe, Dutton, Sonenshein \& Grant, 2005). Both vitality and learning pertained to the emotional and cognitive psychological perspectives of personal development (Porath, Spreitzer, Gibson \& Garnett, 2012) and are examined in terms of the human life span (e.g., Tremethick, 1997), various situations such as hardship (e.g., O'Leary \& Ickovics, 1995), job environments (e.g., Sumsion, 2004) and youth development (e.g., Gestsdottir, Urban, Bowers, Lerner \& Lerner, 2011). Many psychosocial sources enhance thriving across diverse contexts and samples. These are categorized as personal sources such as heedful relating and contextual sources such as broad information sharing (Spreitzer et al., 2005). In this study, spirituality and vitality will be considered as personal sources in thriving among university students. Tomasik, Napolitano and Moser (2019) have commented that thriving has a place in the developmental context of the individual, which is shaped by the interactions that one experiences past and present. Thriving provides individuals with the ability to fairly assess what they are doing, how they are doing and to improve in a positive way (Spreitzer et al., 2005). Thus, a person's abilities to handle life situations and difficulties may be boosted (Hall et al., 2009; Thomas \& Hall, 2008). In this context, life satisfaction may be increased by thriving in university students.

Life satisfaction is a positive assessment of a person's entire life in accordance with the criteria set by that person (Diener, Emmons, Larsen \& Griffin, 1985; Veenhoven, 1996). Life satisfaction is considered as a cognitive component of subjective well-being and includes comparisons between the criteria imposed by the individual and their perception of their living conditions, and so acts as an assessment of their lives (Dorahy et al., 2000). Psychological sources, such as personal features and having a relationship, are stated as the main factors of life satisfaction - although it is generally assumed that gender, income and race are main factors (Myers \& Diener, 1995). In this context, it can be claimed those with more positive psychological sources may achieve greater life satisfaction. There are many different psychological sources for life satisfaction among the university students, such as healthy relationships (Schnettler et al., 2017), social support (Alorani \& Alradaydeh, 2018), spirituality (Parpoochi, Ahmadi \& Sohrabi, 2013) and so on. However, thriving may also provide personal-psychological sources with learning and vitality which may provide further life satisfaction.

In all of the abovementioned studies, the relationship between thriving and life satisfaction may be described by the Conservation of Resources theory offered by Hobfoll (2011). According to this model, the 
Ozcan, N. A., \& Yaman N., (2020). The mediating role of spiritual orientation and subjective vitality in university students. Cypriot Journal of Educational Science. 15(5), 909 - 922. https://doi.org/10.18844/cjes.v15i5.5121

material and psychological sources of individuals can help them better cope with life situations more easily, improve them positively and give them greater satisfaction. Furthermore, many studies have indicated the relationship between thriving and life satisfaction (Flinchbaugh, Luth \& Li, 2015; Morgan Consoli, Llamas \& Consoli, 2016; Zhai, Wang \& Weadon, 2020). However, still there has been no study carried out on the underlying psychological resources that may explain the relationship between thriving and life satisfaction, especially among the university students. In this regard, it is posited that the underlying resources in the relationship between thriving and life satisfaction may occur in the form of spiritual orientation and vitality.

\subsection{The mediator role of spiritual orientation in the relationship between thriving and life satisfaction}

The American Psychological Association defines human beings as biopsychosocial spiritual beings (APA, 1994). Nowadays, spirituality gained increased importance in the field of psychology (Dailey, Curry, Harper, Hartwig-Moorhead \& Gill, 2011; Powers, 2005). Myers, Sweeney and Witmer (2000) defined spirituality as the quality of human existence, which contains a sense of strength or existence that goes beyond the substance aspect of life, and a profound meaning of loyalty and integrity to the universe. Furthermore, many studies have indicated that spirituality empowers individuals (Kilpatrick \& McCullough, 1999; Martinez \& Scott, 2014). Many spiritual ideas and activities encourage respect (Hendrick \& Hendrick, 2002), forgiveness (Dierendonck \& Mohan, 2006), etc. There are also many studies emphasising that spirituality has a positive role in the growth of youth (Astin, Astin \& Lindholm, 2011; Kuh \& Gonyea, 2006). In this regard, spirituality is quite related to thriving. Young people with a spiritual lifestyle has much more social engagement (Astin et al., 2011; Kuh \& Gonyea, 2006). Thus, these social engagements may increase social skills and interactions that lead young people to be vital and to engage in learning. In line with these explanations, many studies have indicated the relationship between thriving and spirituality in adolescents (Dowling et al., 2004; Lerner, Brentano, Dowling \& Anderson, 2002).

Furthermore, some studies have indicated a relationship between spirituality and life satisfaction (Kelley \& Miller, 2007), while several others have emphasized that spirituality has a positive role in the life satisfaction of young people (Khan, Shriaz \& Ahmed, 2011; Kim, Miles-Mason, Kim \& Esquivel, 2013). A number of studies, meanwhile, have emphasized that spirituality allows for a greater degree of acquisition of meaning in life (Martinez \& Scott, 2014; Stewart, 2009) and the overcoming challenges (Constantine, Miville, Warren, Gainor \& Lewis-Coles, 2006). In this context, many studies indicated that spirituality provides university students to better adapt to university life (Alorania \& Alradaydeh, 2018; Kneipp, Kelly \& Cyphers, 2009) and to get more life satisfaction (Alorania \& Alradaydeh, 2018; Abdel-Khalek, 2010). In line with these studies, adolescence - as a period in which identity is formed - is a time when denoting about life via spirituality can lead to a more satisfying evaluation of life. However, there is no study pertaining to the relationship between thriving, spirituality, and life satisfaction.

\subsection{The mediator role of subjective vitality in the relationship between thriving and life satisfaction}

Subjective vitality can be defined as subjective experiences that are accompanied by alive, positive emotions (Greenglass, 2006; Ryan \& Frederick, 1997). People who experience subjective vitality are lively, energetic, having vital internal source and zealous (Fini, Kavousian, Beigny \& Emami, 2010; Nix, Ryan, Manly \& Deci, 1999). Moreover, subjective vitality is associated with openness to experience (Deniz \& Satici, 2017; Fini et al., 2010). Openness to experience provides individuals with intellectual curiosity, the ability to foster new ideas and having unconventional thought processes (McCrae \& Costa, 1997). To have openness, individuals - especially university students - need to engage in social life and to learn. Thus, subjective vitality may be increased through engagement in social life and learning experiences. In this context, subjective vitality is related to thriving. Thriving includes both vitality and learning to improve in a positive way (Spreitzer et al., 2005). Thus, thriving provides individuals, especially university students, with the ability to deal with life issues and develop an upward growth (Hall et al., 2009; Thomas \& Hall, 
2008). Ryan \& Deci (2008) have also stated that subjective vitality also boosts productivity and the capability to deal with stress. In this regard, subjective vitality may provide university students with the energy to thrive with developmental difficulties and to reach their own standards. In all these explanations, it is stated that thriving and subjective vitality may be seen more as an interwoven concept, but there have not been any studies in the literature that show the relationship between thriving and subjective vitality.

Furthermore, subjective vitality manifests as a positive and dynamic emotional structure that covers physical and psychological wellness (Nix et al., 1999; Ryan \& Frederick, 1997). Therefore, subjective vitality is related to subjective well-being (Niemiec et al., 2006; Salama-Younes, 2011). Subjective well-being has affective and cognitive domains (Diener, 2000). In this context, life satisfaction is the subjective and cognitive self-evaluations of the person's overall life quality, and a cognitive part of subjective well-being (Dorahy et al., 2000). Moreover, there are many studies (Celik, 2017; Fini et al., 2010; Salama-Younes, 2011) indicating the relationship between subjective vitality and life satisfaction in university students.

The abovementioned studies have indicated the importance of thriving, spiritual orientation as well as subjective vitality in life satisfaction among university students. When the literature is examined, there appears no study that examines these variables at the same time. In this context, the study aims to examine the theoretical model developed for the mediating role of the spiritual orientation and subjective vitality, in the association between university students' thriving and life satisfaction. Furthermore, this study contributes to the literature by addressing the importance of spirituality and subjective vitality for university students to thrive with life and to get life satisfaction. Within response to the findings acquired by this study, it is believed that experts will consider about thriving, spiritual orientation and subjective vitality in the interventions related to life satisfaction to university students. With the programs developed considering the results of this research, university students can better adapt to both situations of university life and real life to thrive and protect their mental health. Thus, the following hypothesis was established in line with the main purpose of the study: "Does spiritual orientation and subjective vitality have a mediating role in the relationship between the thriving and life satisfaction of university students?". The structural model constructed in this study is presented in Figure 1.

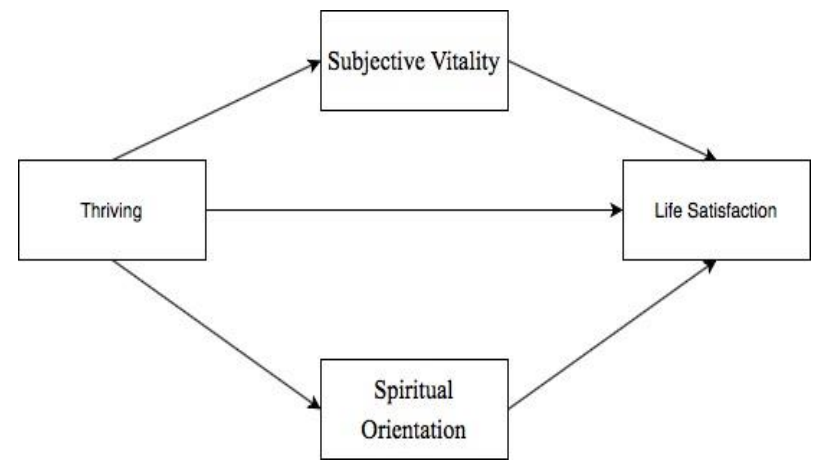

Figure 1. Hypothetical model related to the study

\section{Method}

\subsection{Research design}

The analysis of the research was conducted with the structural equation model (SEM). SEM is one of the broadest statistical techniques used to examine the causal and correlational relationships between observed and unobserved (latent) variables (Hoyle, 1995). In other words, the structural equation model gathers the predictor structural relationship between the variables in the regression model and the latent factor structures in factor analysis in a comprehensive analysis (Sumer, 2000). In SEM, a detailed presentation of all the parameters related to the relationships between variables in the model is referred 
to as model building (Simsek, 2007). In this study, a review of Hooper, Coughlan and Mullen (2008) was taken into consideration for the evaluation of the fit indices. On the other hand, the bootstrapping test was used to examine whether the mediation was significant or not.

\subsection{Participants}

The study group consisted of students studying at Istanbul Medeniyet University. A total of 527 students, $428(81.2 \%)$ females and 99 (18.8\%) males, participated in the study. The age range of the group was between 18 and 28 years, and the average was 20 years $(S D=2.35)$.

\subsection{Research instruments and procedures}

The Thriving Scale, the Satisfaction with Life Scale, the Spiritual Orientation Scale and the Subjective Vitality Scale were all used to collect data.

\subsubsection{Thriving scale}

The scale developed by Porath et al. (2012) was adapted into Turkish for an academic context by AriciOzcan, Sahin and Cankir (2020). The scale has 10 items with a 6-point Likert-type scale. Vitality and learning were subdimensions of the scale. The original version's overall internal consistency was 0.92 for adult people, and 0.88 for young professional samples. The Turkish scale of the CFA of thriving scale was tested with two time lines and subdimensions fit the data well at T1 $\left(\chi^{2} / \mathrm{df}=1.616, \mathrm{CFI}=0.981, \mathrm{IFI}=982\right.$, RMSEA $=0.077, \mathrm{SRMR}=0.046)$ and $\mathrm{T} 2\left(\chi^{2} / \mathrm{df}=1.778, \mathrm{CFI}=0.978, \mathrm{IFI}=978, \mathrm{RMSEA}=0.068, \mathrm{SRMR}=0.049\right)$. All factor loadings were significant $(p<0.01)$. The Cronbach alpha coefficient between T1 and T2 for thriving came to $.775(95 \% \mathrm{Cl} ; 0.69-0.83)$. The Cronbach alpha coefficient of this study came to 0.66 .

\subsubsection{The satisfaction with life scale}

This scale was developed by Diener et al. (1985) and adapted into Turkish by Durak, Senol-Durak and Gencoz (2010). The scale is a five-item 7-point Likert-type scale. The validity of the Turkish form was tested with the confirmatory factor analysis (CFA). The CFA reflected the one factor. The model has suitable fit indices $\left(\chi^{2} / \mathrm{df}=2.93, \mathrm{TLI}=0.98, \mathrm{IFI}=0.99, \mathrm{CFI}=0.99, \mathrm{RMSEA}=0.043\right)$. The Cronbach alpha coefficient came to 0.81 in the Turkish version (Durak et al., 2010). Moreover, the present study of the Cronbach alpha coefficient came to 0.79 .

\subsubsection{Spiritual orientation scale}

This self-report scale was developed by Kasapoglu (2015). It has 16 items with 7-point Likert-type scale. Exploratory and confirmatory factor analyses were performed to examine the construct validity of the scale. A scale consisting of one factor explaining $47.50 \%$ of the total variance of the scale and suitable for the fit indices $\left(\chi^{2}=239.718, \mathrm{SD}=100, p=0.000\right), \chi^{2} / \mathrm{SD}=2.39, \mathrm{RMSEA}=0.06, \mathrm{RMR}=0.05, \mathrm{GFI}=0.93, \mathrm{AGFI}$ $=0.90, \mathrm{CFI}=0.95, \mathrm{IFI}=0.95, \mathrm{NFI}=0.92)$. Cronbach alpha internal consistency coefficient of the scale came to .87 . The test-retest reliability coefficient of the scale was 0.85 .

\subsubsection{Subjective vitality scale}

This is a seven-item 7-point Likert-type self-report scale developed by Ryan and Frederick (1997) and was adapted into Turkish by Akin, Satici, Arslan, Akin and Kayis (2012). In terms of the confirmatory factor analysis of the Turkish version, the scale has two dimensions in its original version, and that the scale was an acceptable fit index (RMSEA $=0.047, \mathrm{CFI}=1.00, \mathrm{GFI}=0.99, \mathrm{AGFI}=0.96, \mathrm{NFI}=0.99, \mathrm{RFI}=1.00, \mathrm{IFI}=$ 1.00). Cronbach alpha of the Turkish version of coefficients came to .84. Furthermore, the Cronbach alpha coefficient of this study came to 0.87 .

The ethical permission was taken from the Marmara University Institute of Educational Sciences Ethical Committee. Data were collected from Istanbul Medeniyet University. Thus, an appropriate sampling 
method was used. Students were randomly chosen and informed about the study to voluntarily participate in this study. Voluntary students confirmed a written informed consent form. Paper-pen format scales were used in the class which lasted approximately 15 minutes.

\subsection{Data analysis}

The theoretical model was built up to find the mediating role of spiritual orientation and subjective vitality. In the connection between university students' thriving and life satisfaction, the model was examined via structural equation modelling. Before the statistical analysis phase, the data were examined in terms of normality, loss values and the existence of extreme values, and the skewness and kurtosis values of the variables were found to be between -1 and +1 . After the data set was found to meet the assumptions in question, the relationships between the variables of thriving, life satisfaction, spiritual orientation and subjective vitality were then tested with the Pearson Product-Moment Correlation Technique before the analyses of the structural equation modelling and mediator variable were conducted.

Baron and Kenny's (1986) criteria were taken into consideration while examining the role of the proposed variables. First, the relationship between independent and dependent variables should be significant. Second, the relationship between the mediating variable and the independent variable should also be significant. Third, there should be a significant relationship between the independent variable, the mediating variable, and the dependent variable. Finally, when the regression analysis is performed simultaneously in the mediator variable and the independent variable, the significant relationship between the independent and dependent variable should no longer be significant or the previous level of significance should be reduced. After these conditions were met, a comparison of the model fit was launched. Last, the bootstrapping test was performed to examine the effect of mediator variables. SPSS 15 and AMOS package software were used for the analyses of the study.

\section{Results}

In this section, the findings obtained as a result of a statistical analysis were given, and the correlation between the variables was first analyzed with the Pearson correlation test. All $p$ values were two-sided reaching a significant $p<0.01$. All correlation results were found to be on the theoretically expected direction and yielded significant results. The correlation values between the variables were shown in Table 1.

Table 1. Means, standard deviations and correlation values of variable

\begin{tabular}{|c|c|c|c|c|c|c|}
\hline Factor & Mean & SD & 1 & 2 & 3 & 4 \\
\hline 1. Thriving & 32.54 & 9.53 & 1 & $0.371 * *$ & $\begin{array}{l}0.137 * \\
*\end{array}$ & $0.467^{* *}$ \\
\hline 2. Life satisfaction & 85.53 & $\begin{array}{l}12.0 \\
8\end{array}$ & & 1 & $\begin{array}{l}0.133^{*} \\
*\end{array}$ & $0.398 * *$ \\
\hline $\begin{array}{l}3 . \quad \text { Spiritual } \\
\text { orientation }\end{array}$ & 29.80 & 3.78 & & & 1 & $0.138 * *$ \\
\hline 4. Subjective vitality & $\begin{array}{l}105.2 \\
7\end{array}$ & $\begin{array}{l}30.1 \\
1\end{array}$ & & & & 1 \\
\hline
\end{tabular}


To conduct analyses on the mediating role of spiritual orientation and subjective vitality in the connection between university students' thriving and life satisfaction, the correlation values had to be appropriate. As seen in Table 1, there was indeed a positive correlation between the variables. After these significant relationships, the testing phase of the model was launched.

\subsection{Mediation test with structural equation modelling}

The existence of the mediating role of the spiritual orientation and subjective vitality, in the connection between university students' thriving and life satisfaction, was investigated via the path analysis method. The established structural path analysis model was tested using AMOS package software. Since using structural equation modelling in mediation tests yields more reliable results than linear regression analyses (Meydan \& Sesen, 2011), a path analysis model was established in this research. The first model was presented in Figure 2.

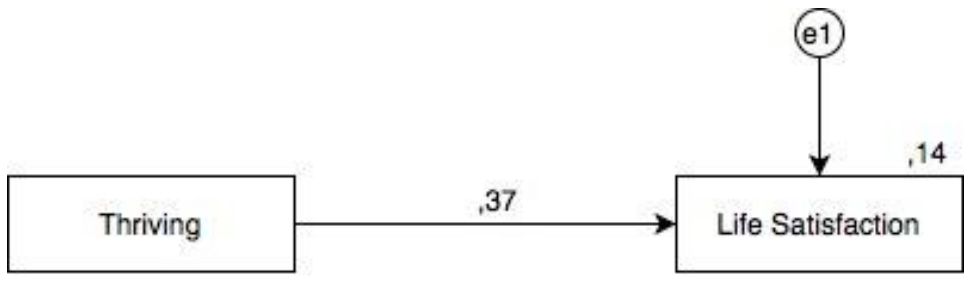

Figure 2 . The model regarding the correlation between thriving and life satisfaction $(* * p<0.01)$

As shown in Figure 2, the correlation between thriving and life satisfaction was found to be significant $(r=$ $0.21 ; p<0.001)$. The compatibility values of this model were given in Table 2 .

Table 2. Results regarding fit values of thriving and life satisfaction model

\begin{tabular}{llll}
\hline & $\begin{array}{l}\text { Mode } \\
\text { I }\end{array}$ & $\begin{array}{l}\text { Excellent fit indicator } \\
\text { criteria }\end{array}$ & $\begin{array}{l}\text { Good fit indicator } \\
\text { criteria }\end{array}$ \\
\hline$\chi^{2} / \mathrm{SD}$ & 0.00 & $\leq 3$ & $3<\chi^{2} / \mathrm{SD} \leq 5$ \\
$\mathrm{RMSEA}$ & 0.02 & $\leq 0.05$ & $0.05<\mathrm{RMSEA} \leq 0.08$ \\
$\mathrm{GFI}$ & 0.96 & $\geq 0.95$ & $0.90 \leq \mathrm{GFI}<0.95$ \\
$\mathrm{NFI}$ & 0.98 & $\geq 0.95$ & $0.90 \leq \mathrm{GFI}<0.95$ \\
$\mathrm{CFI}$ & 0.96 & $\geq 0.95$ & $0.90 \leq \mathrm{GFI}<0.95$ \\
\hline
\end{tabular}

As shown in Table 2, the fit values of the model are within acceptable limits $\left(\chi^{2} / \mathrm{SD}=0.00 ; p<0.01 ; \mathrm{GFI}=\right.$ $0.96 ; \mathrm{CFI}=0.96 ; \mathrm{NFI}=0.98 ; \mathrm{RMSEA}=0.02$ ). Following this process, the model was re-established by including the variables of restrictive beliefs in the attitude of the mate selection and the meaning attributed to the marriage. 


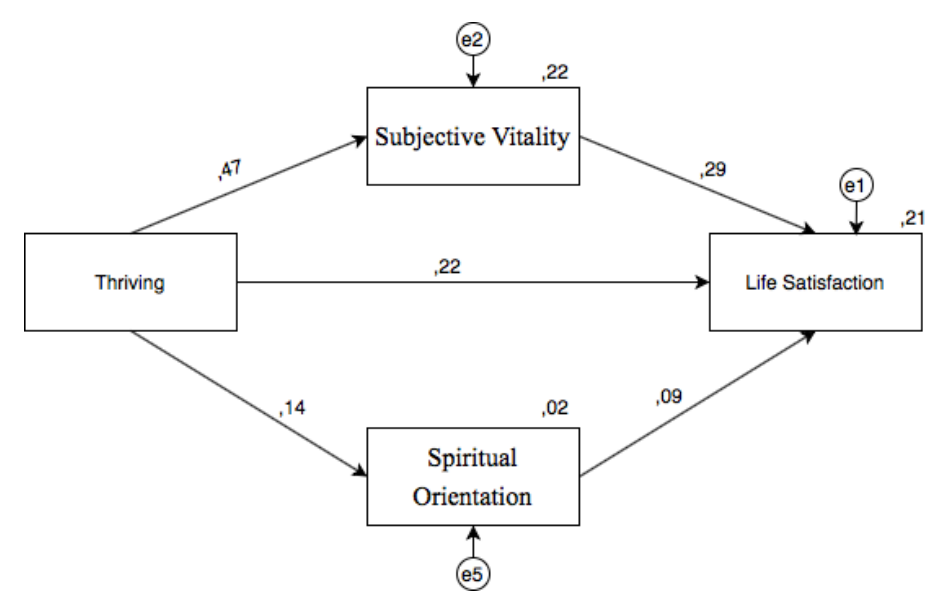

Figure 3. Thriving-spiritual orientation-subjective vitality in the life satisfaction structural equation modelling $\left(p<0.05^{*}\right)$

In the second model (Figure 3), spiritual orientation and subjective vitality were included in the model as mediating variables. When the model was examined, both variables were seen to have a partial mediator role effect. In this context, while in the first model, the correlation was $(r=0.37)$, due to the mediator role of variables, it decreased to $(r=0.22)$. Therefore, it is possible to say that spiritual orientation and subjective vitality have a partial mediator role effect on the correlation between thriving and life satisfaction and relationship satisfaction. The fit values of this model were presented in Table 3.

Table 3. Results regarding fit values of thriving-spiritual orientation-subjective vitality in the life satisfaction model

\begin{tabular}{llll}
\hline & $\begin{array}{l}\text { Mode } \\
\text { I Excellent fit indicator } \\
\text { criteria }\end{array}$ & $\begin{array}{l}\text { Good fit indicator } \\
\text { criteria }\end{array}$ \\
\hline$\chi^{2} / \mathrm{SD}$ & 0.00 & $\leq 3$ & $3<\chi^{2} / \mathrm{SD} \leq 5$ \\
$\mathrm{RMSEA}$ & 0.00 & $\leq 0.05$ & $0.05<\mathrm{RMSEA} \leq 0.08$ \\
$\mathrm{GFI}$ & 0.99 & $\geq 0.95$ & $0.90 \leq \mathrm{GFI}<0.95$ \\
$\mathrm{NFI}$ & 0.99 & $\geq 0.95$ & $0.90 \leq \mathrm{GFI}<0.95$ \\
$\mathrm{CFI}$ & 0.1 & $\geq 0.95$ & $0.90 \leq \mathrm{GFI}<0.95$
\end{tabular}

As shown in Table 3, the fit values of the model are within acceptable limits $\left(\chi^{2} / \mathrm{SD}=0.00 ; p<0.01 ; \mathrm{GFI}=\right.$ 0.99; $\mathrm{CFI}=0.1 ; \mathrm{NFI}=0.99 ; \mathrm{RMSEA}=0.00$ ). 
Ozcan, N. A., \& Yaman N., (2020). The mediating role of spiritual orientation and subjective vitality in university students. Cypriot Journal of Educational Science. 15(5), 909 - 922. https://doi.org/10.18844/cjes.v15i5.5121

Table 4. Bootstrapping of the model

\begin{tabular}{|c|c|c|c|c|c|}
\hline \multicolumn{4}{|c|}{ Model paths } & \multicolumn{2}{|c|}{ 95\% BCa confidence interva } \\
\hline Mo & & & Coefficient & Low & High \\
\hline \multicolumn{6}{|c|}{ Direct } \\
\hline SO & $\mathrm{T}$ & & 0.281 & 0.162 & 0.334 \\
\hline SV & $\mathrm{T}$ & & 0.380 & 0.402 & 0.314 \\
\hline LS & $\mathrm{T}$ & & 0.400 & 0.378 & 0.274 \\
\hline \multicolumn{6}{|c|}{ Indirect } \\
\hline LF & SO-SO & $\mathrm{T}$ & 0.054 & 0.022 & 0.118 \\
\hline
\end{tabular}

Table 4 shows the results of the bootstrapping process, where the total values of both directly and indirectly measured coefficients in the model prove to be significant (bootstrap coefficient model $=0.054$, $95 \%$ G.A. $=0.022,0.118$ ). According to the obtained results, spiritual orientation and subjective vitality have a partial mediator role effect in the correlation between thriving and life satisfaction.

\section{Discussion and Conclusion}

This study aimed to examine the mediating role of spiritual orientation and subjective vitality in the relationship between thriving and life satisfaction among university students. The resulting model fit indicated that the model corresponds with the data.

The first results of the research indicated that the direct influence of thriving to life satisfaction in university students was statistically significant. Many studies have shown the relationship between thriving and life satisfaction among university students (Flinchbaugh et al., 2015; Zhai et al., 2020) as being parallel to the findings of this study. All have indicated that thriving provides many resources with vitality and learning, which have a role in life satisfaction. However, none of these studies went on to identify the underlying resources that describe the relationship between thriving and life satisfaction. With this in mind, it is thought that spirituality is related to both thriving and life satisfaction.

According to the second result of the research, the mediating role of spirituality in the relationship between thriving and life satisfaction among university students was found. These relationships may be explained through the social engagement inherent in thriving. Spirituality may allow university students to engage in some spiritual rituals that require social interactions and skills. In these social engagements, adolescents may be open to learning, which may lead them to evaluate the world in a more meaningful and satisfying way. In parallel to these, most of the studies about both the relationship between thriving and spirituality among university students (Dowling et al., 2004; Lerner et al., 2002) and the relationship between life satisfaction and spirituality among university students (Khan et al., 2011; Kim et al., 2013) support this result of this research. It can be said that the results from this study and other studies, spirituality may empower university students to thrive with university and life challenges and to get better life satisfaction. 
Another result of the study found the mediating role of subjective vitality in the relationship between thriving and life satisfaction. Many studies (Deniz \& Satici, 2017; Fini et al., 2010) have indicated that subjective vitality provides university students with an openness to experience in their social lives. This openness from subjective vitality may provide university students with the ability to participate in social activities that may guide them to thrive and deal with difficulties in a positive way. In this context, thriving and subjective vitality may be intertwined, but there have been no studies about their relationship. Thus, this study is the first to indicate a relationship between thriving and subjective vitality.

Furthermore, subjective vitality enhances well-being (Nix et al., 1999; Ryan \& Frederick, 1997). In addition, life satisfaction is the cognitive part of well-being and may be increased by subjective vitality. University students experience subjective vitality in evaluating their life and their standards in a more positive way. In line with this, many studies centered in the relationship between life satisfaction and subjective vitality among university students (Celik, 2017; Fini et al., 2010; Salama-Younes, 2011) support our findings. It can be inferred from the results of this study that subjective vitality may provide university students with energy to deal with challenges and to evaluate their life in a better way.

The study is not without a number of limitations, however. First, the results of the study have been acquired from self-report scales, which may have biases in the answers, as individuals tend to be defensive and present themselves well in self-report-based evaluations. Second, the sample group was limited to a group studying in one university only. Adolescents studying in different universities could be included in a similar sample group. However, despite all these limitations, it is thought that this research will contribute to the literature by revealing the importance of life satisfaction in university students who have subjective vital and spiritual orientation and thrive with what life brings. Based on the data from this study, to increase the life satisfaction of university students, some social programs including curiosity and energetic activities, or spiritual features may be organized by university clubs, lecturers, counsellors, etc. Furthermore, counsellors may develop and implement life satisfaction and thriving guidance program for university students by adding a sense of subjective vitality and spirituality.

\section{References}

Abdel-Khalek, A. M. (2010). Quality of life, subjective well-being, and religiosity in Muslim college students. Quality of Life Research, 19, 1133-1143. doi:10.1007/s11136-010-9676-7

Akin, A., Satici, S. A., Arslan, S., Akin, U. \& Kayis, A. R. (2012). The validity and the reliability of the Turkish version of the subjective vitality scale (SVS). Paper presented at the 4th World Conference on Educational Sciences, 25 February, Barcelona, Spain.

American Psychiatric Association, APA (1994). Diagnostic and statistical manual of mental disorders: DSM-IV (4th ed.). Washington, DC: American Psychiatric Association. doi:10.1017/s0033291700035765

Alorani, O. I. \& Alradaydeh, M. F. (2018). Spiritual well-being perceived social support and life satisfaction among university students. International Journal of Adolescence and Youth, 23(3), 291-298. doi:10.1080/02673843.2017.1352522

American Psychiatric Association (1994). Diagnostic and statistical manual of mental disorders (4th ed.). Washington, DC: Author. doi:10.1176/ajp.152.8.1228

Astin, A. W., Astin, H. S. \& Lindholm, J. A. (2011). Cultivating the spirit: how college can enhance students' inner lives. San Francisco, CA: Jossey-Bass. doi:10.1080/02604027.2011.578041

Arici-Ozcan, N., Sahin, S. \& Cankir, B. (2020). The validity and reliability of thriving scale in academic context: mindfulness, GPA, and entrepreneurship among university students (Unpublished Manuscript).

Baron, R. M. \& Kenny, D. A. (1986). The moderator-mediator variable distinction in social-psychological research: conceptual, strategic, and statistical considerations. Journal of Personality and Social Psychology, 51, 11731182. doi:10.1037/0022-3514.51.6.1173 
Ozcan, N. A., \& Yaman N., (2020). The mediating role of spiritual orientation and subjective vitality in university students. Cypriot Journal of Educational Science. 15(5), 909 - 922. https://doi.org/10.18844/cjes.v15i5.5121

Benson, P. L., Scales, P. C., Hamilton, S. F. \& Sesma, A. (2007). Positive youth development: theory, research, and applications. In W. Damon \& R. M. Lerner (Eds.), Handbook of child psychology (6th ed., vol. 1, pp. 894-941). New York: Wiley. doi:10.1002/9780470147658.chpsy0116

Bundick, M. J., Yeager, D. S., King, P. E. \& Damon, W. (2010). Thriving across the life span. In W. F. Overton \& R. M. Lerner (Eds.), The handbook of life-span development, Vol. 1. Cognition, biology, and methods. Hoboken, NJ: John Wiley \& Sons Inc. doi:10.1002/9780470880166.hlsd001024

Constantine, M. G., Miville, M. L., Warren, A. K., Gainor, K. A. \& Lewis-Coles, M. A. E. (2006). Religion, spirituality, and career development in African American college students: A qualitative inquiry. The Career Development Quarterly, 54(3), 227-241. doi:10.1002/j.2161-0045.2006.tb00154.x

Celik, E. (2017). Examining the mediating effect of subjective vitality in the proactive personality and life satisfaction relationship. International Journal of Happiness Development, 3, 289-302. doi:10.1504/ijhd.2017.087929

Dailey, S. F., Curry, J. R., Harper, M. C., Hartwig Moorhead, H. J. \& Gill, C. S. (2011). Exploring the spiritual domain: tools for integrating spirituality and religion in counseling. Retrieved from http://counselingoutfitters.com/vistas/vistas11/Article_99.pdf

Diener, E. (2000). Subjective well-being: the science of happiness and a proposal for a national index. American Psychologist, 55(1), 34. doi:10.1037/0003-066x.55.1.34

Diener, E., Emmons, R. A., Larsen, R. J. \& Griffin, S. (1985). The satisfaction with life scale. Journal of Personality Assessment, 49, 71-75. doi:10.1207/s15327752jpa4901_13

Dierendonck, D. V. \& Mohan, K. (2006). Some thoughts on spirituality and eudemonic well-being. Mental Health, Religion, and Culture, 9(03), 227-238. doi:10.1080/13694670600615383

Dorahy, M. J., Lewis, C. A., Schumaker, J. F., Akuamoah-Boateng, R., Duze, M. C. \& Sibiya, T. E. (2000). Depression and life satisfaction among Australian, Ghanaian, Nigerian, Northern Irish, and Swazi university students. Journal of Social Behavior and Personality, 15(4), 569. doi:10.1016/s0191-8869(97)00191-8

Durak, M., Senol-Durak, E. \& Gencoz, T. (2010). Psychometric properties of the satisfaction with life scale among Turkish university students, correctional officers, and elderly adults. Social Indicators Research, 99(3), 413429. doi:10.1007/s11205-010-9589-4

Dowling, E. M., Gestsdottir, S., Anderson, P. M., Von Eye, A., Almerigi, J. \& Lerner, R. M. (2004). Structural relations among spirituality, religiosity, and thriving in adolescence. Applied Developmental Science, 8(1), 7-16. doi:10.1207/s1532480xads0801_2

Deniz, M. E. \& Satici, S. A. (2017). The relationships between big five personality traits and subjective vitality. Annals of Psychology, 33(2), 218-224. doi:10.6018/analesps.33.2.261911

Fini, A. A. S., Kavousian, J., Beigy, A. \& Emami, M. (2010). 'Subjective vitality and its anticipating variables on students'. Procedia - Social and Behavioral Sciences, 5, 150-156. doi:10.1016/j.sbspro.2010.07.064

Flinchbaugh, C., Luth, M. T. \& Li, P. (2015). A challenge or a hindrance? Understanding the effects of stressors and thriving on life satisfaction. International Journal of Stress Management, 22(4), 323-345. doi:10.1037/a0039136

Gestsdóttir, S., Urban, J. B., Bowers, E. P., Lerner, J. V. \& Lerner, R. M. (2011). Intentional self-regulation, ecological assets and thriving in adolescence: a developmental systems model. New Directions for Child and Adolescent Development, 2011(133), 61-76. doi:10.1002/cd.304

Greenglass, E. R. (2006). Vitality and vigor: Implications for healthy functioning. In P. Buchwald (Ed.), Stress and anxiety application to health, workplace, community, and education. Newcastle, UK: Cambridge Scholars Press. Retrieved from https://psycnet.apa.org/record/2013-15049-004

Hall, J. M., Roman, M. W., Thomas, S. P., Travis, C. B., Powell, J., Tennison, C. R., ... \& Martin, T. (2009). Thriving as becoming resolute in narratives of women surviving childhood maltreatment. American Journal of Orthopsychiatry, 79(3), 375-386. doi:10.1037/a0016531 
Ozcan, N. A., \& Yaman N., (2020). The mediating role of spiritual orientation and subjective vitality in university students. Cypriot Journal of Educational Science. 15(5), 909 - 922. https://doi.org/10.18844/cjes.v15i5.5121

Hamdan-Mansour, A., Halabi, J., \& Dawani, H. (2008). Depression, hostility, and substance use among university students in Jordan. Mental Health and Substance Use, 2, 52-63. doi:10.1080/17523280802593301

Hendrick, S. S. \& Hendrick, C. (2002). Linking romantic love with sex: Development of the perceptions of love and sex scale. Journal of Social and Personal Relationships, 19(3), 361-378. doi:10.1177/0265407502193004

Hobfoll, S. E. (2011). Conservation of resources theory: its implication for stress, health, and resilience. The Oxford Handbook of Stress, Health, and Coping, 127, 147. doi:10.1093/oxfordhb/9780195375343.013.0007

Hooper, D., Coughlan, J. \& Mullen, M. (2008). Structural equation modelling: Guidelines for determining model fit. The Electronic Journal of Business Research Methods, 6, 53-60. Retrieved from https://arrow.tudublin.ie/cgi/viewcontent.cgi?article=1001\&context=buschmanart.

Howard, D. E., Schiraldi, G., Pineda, A., \& Campanella, R. (2006). Stress and mental health among college students: Overview and promising prevention intervention. In M. V. Landow (Ed.), Stress and mental health of college students (pp. 91-123). New York: Nova Science

Hoyle, R. H. (1995). The structural equation modeling approach: Basic concepts and fundamental issues. In R. H. Hoyle (Ed.), Structural equation modeling: concepts, issues, and applications (pp. 1-15). Thousand Oaks, CA: Sage Publications, Inc. doi:10.2307/3151904

Kasapoglu, F. (2015). Development of spiritual orientation scale: the study of validity and reliability. Inonu University Journal of the Faculty of Education, 16(3), 51-68. https://toad.halileksi.net/sites/default/files/pdf/maneviyonelim-olcegi-toad.pdf

Kelley, B. S. \& Miller, L. (2007). Life satisfaction and spirituality in adolescents. Research in the Social Scientific Study of Religion, 18, 233-261. Retrieved from https://brill.com/view/book/edcoll/9789047419648/Bej.9789004158511.i-301_014.xml

Khan, M., Shirazi, M. \& Ahmed, M. (2011). Spirituality and life satisfaction among adolescents in India. Journal of Subcontinent Researches, 3(7), 71-84. Retrieved from http://jsr.usb.ac.ir/article_437_af9efe75245f2a1240740ea9b96883c8.pdf

Kim, S., Miles-Mason, E., Kim, C. Y. \& Esquivel, G. B. (2013). Religiosity/spirituality and life satisfaction in Korean American adolescents. Psychology of Religion and Spirituality, 5(1), 33-40. doi:10.1037/a0030628

Kilpatrick, S. D. \& McCullough, M. E. (1999). Religion and spirituality in rehabilitation psychology. Rehabilitation Psychology, 44, 388-402. doi:10.1037/0090-5550.44.4.388

Kleine, A. K., Rudolph, C. W. \& Zacher, H. (2019). Thriving at work: a meta-analysis. Journal of Organizational Behavior, 40, 973-999. doi:10.1002/job.2375

Kneipp, L. B., Kelly, K. E. \& Cyphers, B. (2009). Feeling at peace with college: religiosity, spiritual well-being, and college adjustment. Individual Differences Research, 7, 188-196.

Kuh, G. D. \& Gonyea, R. M. (2006). Spirituality, liberal learning, and college student engagement. Liberal Education, 92(1), 40-47. Retrieved from https://files.eric.ed.gov/fulltext/EJ743277.pdf

Kurtines, W. M., Ferrer-Wreder, L., Berman, S. L., Cass Lorente, C., Silverman, W. K. \& Montgomery, M. J. (2008). Introduction to special issue on promoting positive youth development: a develop- mental intervention approach-new developments in developmental theory, methods, and research. Journal of Adolescent Research, 23, 233-244. doi:10.1177/0743558408314372.

Lerner, R. M., Brentano, C., Dowling, E. M. \& Anderson, P. M. (2002). Positive youth development: thriving as the basis of personhood and civil society. New Directions for Youth Development, 2002(95), 11-34. doi:10.1002/yd.14

Lerner, R. M., Lerner, J. V., Bowers, E. P. \& Geldhof, G. J. (2015). Positive youth development and relationaldevelopmental-systems. Handbook of child psychology and developmental science. New York: Wiley. 
Ozcan, N. A., \& Yaman N., (2020). The mediating role of spiritual orientation and subjective vitality in university students. Cypriot Journal of Educational Science. 15(5), 909 - 922. https://doi.org/10.18844/cjes.v15i5.5121

Lerner, R. M. Von Eye, A., Lerner, J. V., Lewin-Bizan, S. \& Bowers, E. P. (2010). The meaning and measurement of thriving in adolescence: finding from the $4-\mathrm{H}$ study of positive youth development. Journal of Youth and Adolescence, 39. doi:10.1007/s10964-010-9531-8.

Martinez, C. T. \& Scott, C. (2014). In search of the meaning of happiness through flow and spirituality. International Journal of Health, Wellness \& Society, 4(1), 37-49. doi:10.18848/2156-8960/CGP/v04i01/41088

McCrae, R. R. \& Costa, P. T. (1997). Conceptions and correlates of openness to experience. In R. Hogan, J. A. Johnson \& S. R. Briggs (Eds.), Handbook of personality psychology (pp. 825-847). Cambridge, MA: Academic Pre. doi:10.1016/b978-012134645-4/50032-9

Meydan, H. C. \& Sesen, H. (2011). Structural equation modeling AMOS applications. Ankara, Turkey: Detay Publishing. Retrieved from https://www.detayyayin.com.tr/urun/yapisal-esitlik-modellemesi-amos-uygulamalari

Morgan Consoli, M. L., Llamas, J. \& Consoli, A. J. (2016). What's values got to do with it? Thriving among Mexican/Mexican American college students. Journal of Multicultural Counseling and Development, 44(1), 49-64. doi:10.1002/jmcd.12036

Myers, D. G. \& Diener, E. (1995). Who is happy?. Psychological Science, 6, 10-19. doi:10.1111/j.14679280.1995.tb00298.x

Myers, J. E., Sweeney, T. J. \& Witmer, J. M. (2000). The wheel of wellness counseling for wellness: A holistic model for treatment planning. Journal of Counseling \& Development, 78(3), 251-266. doi:10.1002/j.15566676.2000.tb01906.x

Niemiec, C. P., Lynch, M. F., Vansteenkiste, M., Bernstein, J., Deci, E. L. \& Ryan, R. M. (2006). The antecedents and consequences of autonomous self-regulation for college: a self-determination theory perspective on socialization. Journal of Adolescence, 29(5), 761-775. doi:10.1016/j.adolescence.2005.11.009

Nix, G. A., Ryan, R. M., Manly, J. B. \& Deci, E. L. (1999). 'Revitalization through self-regulation: the effects of autonomous and controlled motivation on happiness and vitality', Journal of Experimental Social Psychology, 35(3), 266-284. doi:10.1006/jesp.1999.1382

O'Leary, V. E. \& Ickovics, J. R. (1995). Resilience and thriving in response to challenge: an opportunity for a paradigm shift in women's health. Women's Health (Hillsdale, NJ), 1(2), 121-142. Retrieved from https://pubmed.ncbi.nlm.nih.gov/9373376/

Parpoochi, B., Ahmadi, M. \& Sohrabi, F. (2013). The relationship of religiousness and social support with life satisfaction among university students (Persian). Knowledge \& Research in Applied Psychology, 14(3), 6068. Retrieved from http://journals.khuisf.ac.ir/jsr-p/article-1-1003-en.html

Pavot, W. \& Diener, E. (2008). The satisfaction with life scale and the emerging construct of life satisfaction. The Journal of Positive Psychology, 3(2), 137-152. doi:10.1080/17439760701756946

Porath, C., Spreitzer, G., Gibson, C. \& Garnett, F. G. (2012). Thriving at work: Toward its measurement, construct validation, and theoretical refinement. Journal of Organizational Behavior, 33(2), $250-275$. doi:10.1002/job.756

Powers, R. (2005). Counseling and spirituality: a historical review. Counseling and Values, 49(3), $217-225$. doi:10.1002/j.2161-007x.2005.tb01024.x

Ryan, R. M. \& Deci, E. L. (2008). A self-determination theory approach to psychotherapy: the motivational basis for effective change. Canadian Psychology, 49(3), 186. doi:10.1037/a0012753

Ryan, R. M. \& Frederick, C. (1997). On energy, personality, and health: subjective vitality as a dynamic reflection of well-being. Journal of Personality, 65(3), 529-565. doi:10.1111/j.1467-6494.1997.tb00326.x

Salama-Younes, M. (2011). Positive mental health, subjective vitality, and satisfaction with life for French physical education students. World Journal of Sport Sciences, 4(2), 90-97. doi:10.1037/e537902012-070 
Ozcan, N. A., \& Yaman N., (2020). The mediating role of spiritual orientation and subjective vitality in university students. Cypriot Journal of Educational Science. 15(5), 909 - 922. https://doi.org/10.18844/cjes.v15i5.5121

Scales, P. C., Benson, P. L., Leffert, N. \& Blyth, D. A. (2000). Contribution of developmental assets to the prediction of thriving among adolescents. Applied Developmental Science, 4(1), 27-46. doi:10.1207/s1532480xads0401_3

Schnettler, B., Miranda-Zapata, E., Grunert, K. G., Lobos, G., Denegri, M., Hueche, C. \& Poblete, H. (2017). Life satisfaction of university students in relation to family and food in a developing country. Frontiers in Psychology, 8, 1522. doi:10.3389/fpsyg.2017.01522

Shek, D. T. L. \& Leung, H. (2013). Positive youth development, life satisfaction, and problem behaviors of adolescents in intact and non-intact families in Hong Kong. Frontiers in Pediatrics, 1, 18. doi:10.3389/fped.2013.00018

Spreitzer, G. M., Sutcliffe, K., Dutton, J., Sonenshein, S. \& Grant, A. M. (2005). A socially embedded model of thriving at work. Organization Science, 16(5), 537-549. doi:10.1287/orsc.1050.0153

Stewart, D. L. (2009). Perceptions of multiple identities among Black College students. Journal of College Student Development, 50(3), 253-270. doi:10.1353/csd.0.0075

Sumsion, J. (2004). Early childhood teachers' constructions of their resilience and thriving: a continuing investigation. International Journal of Early Years Education, 12(3), 275-290. doi:10.1080/0966976042000268735

Sun, R. C. F. \& Shek, D. T. L. (2013). Longitudinal influences of positive youth development and life satisfaction on problem behaviour among adolescents in Hong Kong. Social Indicators Research, 114(3), 1171-1197. doi:10.1007/s11205-012-0196-4

Sumer, N. (2000). Structural equation models: basic concepts and sample applications. Turkish Psychological Articles, 3(6), 49-74. Retrieved from http://www.nebisumer.com/wpcontent/uploads/2015/03/SumerN.2000.YEM_TPY.pdf

Simsek, O. F. (2007). Introduction to structural equation modeling; basic principles and LISREL applications. Ankara, Turkey: Ekinoks. Retrieved from https://www.babil.com/yapisal-esitlik-modellemesine-giris-temel-ilkelerve-lisrel-uygulamalari-kitabi-omer-faruk-simsek

Thomas, S. P. \& Hall, J. M. (2008). Life trajectories of female child abuse survivors thriving in adulthood. Qualitative Health Research, 18(2), 149-166. doi:10.1177/1049732307312201

Tomasik, M. J., Napolitano, C. M. \& Moser, U. (2019). Trajectories of academic performance across compulsory schooling and thriving in young adulthood. Child Development, 90(6), e745-e762. doi:10.1111/cdev.13150

Tremethick, M. J. (1997). Thriving, not just surviving the importance of social support among the elderly. Journal of Psychosocial Nursing and Mental Health Services, 35(9), 27-31. Retrieved from https://pubmed.ncbi.nlm.nih.gov/9298462/

Veenhoven, R. (1996). The study of life satisfaction. In W. E. Saris, R. Veenhoven, A. C. Scherpenzeel \& B. Bunting (Eds.), A comparative study of satisfaction with life in Europe (pp. 11-48). Budapest, Hungary: EOtvOs University Press. Retrieved from https://personal.eur.nl/veenhoven/Pub1990s/96d-full.pdf

Walumbwa, F. O., Muchiri, M. K., Misati, E., Wu, C. \& Meiliani, M. (2018). Inspired to perform: a multilevel investigation of antecedents and consequences of thriving at work. Journal of Organizational Behavior, 39(3), 249-261. doi:10.1002/job.2216

Zhai, Q., Wang, S. \& Weadon, H. (2020). Thriving at work as a mediator of the relationship between workplace support and life satisfaction. Journal of Management \& Organization, 26(2), $168-184$. doi:10.1017/jmo.2017.62 